\title{
STANDARDS AND NEEDS OF A NEWLY FORMED VASCULAR SURGERY CENTER
}

\section{STANDARDI I POTREBE NOVOFORMIRANOG CENTRA ZA VASKULARNU HIRURGIJU}

\author{
Vladimir Popović', Nenad Đorđević, Nenad llijevski2,3, Petar Popov², Slobodan Tanasković2
}

\section{Summary}

Defining standards for establishing a new vascular surgery center is very important in order to ensure its proper functioning. Multidisciplinary approach is crucial for optimal functionality of the center. Organizational and technical guidelines should be based on the experience of well - established and recognized vascular surgery centers. The aim of this paper is to highlight the basic needs and requirements for the creation of a vascular center with special emphasis on the quality of cooperation between different specialties.

Key words: vascular surgery, vascular center, establishing.

\section{Sažetak}

Definisanje standarda za formiranje novog centra za vaskularnu hirurgiju je veoma važno u cilju njegovog pravilnog funkcionisanja.Multidisciplinarni pristup je neophodan za optimalno funkcionisanje centra. Organizacione i tehničke smernice bi trebalo da budu bazirane na iskustvima renomiranih savremenih centara za vaskularnu hirurgiju.Cilj ovog rada je da istakne osnovne potrebe i uslove za kreiranje vaskularnog centra sa posebnim akcentom na kvalitet i vrstu saradnje medju stručnjacima različitih specijalnosti.

Ključne reči: vaskularna hirurgija,vaskularni centar, formiranje

Vascular centers have been proposed to integrate the optimal care of patients with vascular diseases. The concept of a vascular center was initially suggested by Elkin and Debakey, who described the benefits of concentration of resources, personnel and data collection for patients with vascular diseases.[1] The term "Vascular Center" began to appear in the professional literature in the mid 90's, predominantly in American publications. [2]

The key word that most accurately defines the term "center" is interdisciplinarity. Multidisciplinary approach to a patient with vascular disease refers not only to optimal diagnosis and initial therapy but also to the treatment of possible future complications. [2] One of the major advantages of close interdisciplinary working relationship is a development of better understanding of each speciality's knowledge and skills and consequently higher efficiency in mutual communication. The essence of an effective vascular center largely depends on a high level of interspeciality communication, mutual respect and sharing responsibilities and resources. [3] Since there is no established template for the creation of a successful vascular center, each institution must address key questions about the current state of the vascular service, possibilities for development and the means of achievement. Individual situation in each institution determines the course of a vascular center development. [4] Various factors may affect the utilization of the newly formed vascular center.
Demographic factors and provider - specific factors, such as a history of specialist utilization are very important. [1]

Despite the fact that there is unique and specific situation in terms of creating vascular center for every individual institution, efforts have been made in order to establish some guidelines and criteria.

In 2002, German Society for vascular surgery published standards for the foundation and certification of vascular centers. [2] According to their standards, vascular center should fulfill the following criteria:

1. Ability to deal with emergency cases

2. Required specialties: vascular surgery, interventional radiology, angiology

3. Adequate number of cases per year

4. Technology-aided diagnostics (computerized tomography (CT), magnetic resonance (MR), intra arterial angiography, Duplex ultrasonography)

5. Adequate operative case numbers

6. Sufficient medical therapy case numbers

7. Training licenses for vascular surgery (since 2006 vascular surgery has been a separate specialty with a minimum of 4 years of training). [2]

Vascular surgery unit in newly formed vascular centers could be established as an independent department or as a part of the general surgical department. [2] As seen 
above, close cooperation between vascular surgeons and interventional radiologists is considered to be essential for optimal management of patients with vascular disease. These two specialties share common patient data base, complementary skills and common interest for emerging technologies like endovascular procedures. Angiologists contribute to the team as a part of the internal medicine department. In the centers where there are no specialized angiologists available, internal physicians or vascular surgeons should be responsible for the conservative treatment of patients with vascular diseases. [2]

Among disciplines which should also be present in vascular centers, neurology should occupy a significant place. A neurologist, as a member of a vascular team, gives an important contribution regarding the criteria of operability for carotid stenosis. Immediate postoperative treatment in vascular surgery involves mandatory neurological monitoring. [8]

Anesthesia specialization on vascular surgical procedures is associated with improved outcomes. As in any surgical endeavor, the obvious goal in anesthesia for vascular surgical procedures is to minimize morbidity and maximize the surgical benefit. [5] As shown by Walsh in retrospective cohort study, vascular anesthesia specialization reduced early (within 30 days of surgery) and medium - term (within two years of surgery) mortality rates following both elective and emergency vascular surgeries. [6]

Cooperation with other specialties, such as cardiology, diabetology or nephrology is very important, particularly in cases where co - existing diseases may cause complications, thus influencing the final outcome of the treatment.

Another important service of the vascular center is vascular diagnostic laboratory. Noninvasive vascular diagnosis is an area of rapidly growing clinical applications and expanding technology. It is a specialized clinical activity requiring a unique background and special skills.
The physician in charge of the vascular diagnostic laboratory should:

1. Understand the instrumentation (and even be able to "troubleshoot" it).

2. Be able to perform and instruct others to perform all non - invasive tests.

3. Obtain and practice a thorough knowledge of the clinical aspects of those vascular diseases being studied in the laboratory.

4. Understand the true meaning, accuracy, and limitations of test results and be able to interpret them in concordance with the other tests and the clinical setting. [7]

Formation, updating and interpretation of the database as a tool used to store and keep track of information relative to activities of the vascular center are significant. Observational data from databases have provided and will continue to provide important findings in the field of vascular surgery. Important findings regarding the incidence or prevalence of vascular disease in the population, mortality, surgery outcomes, national trends, disparities in healthcare delivery, and other insights are valuable source and can be used to improve the quality of the vascular center. [9]

After the consideration of the most important components of the ideal vascular center, another crucial question rises - how should these components merge in one harmonious and efficient assembly?

Organizing and improving the performance of a newly formed vascular center through multidisciplinary approach is a "trial and error" process distinctive for each institution individually. Guidelines in that process should follow the experience of recognized centers whose functionality is well - established. Educational resources (lectures, communication between individuals and institutions, joint projects) are an important link in the chain of forming a respectable vascular center as well.

\section{References}

1. Karamanlou, T., Laudry, G., Sexton, G., Chan, B., Moneta, G., and Taylor, L. Creating a useful vascular center: a statewide survey of what primary care physicians really want. J Vasc Surg.apr. 2004:39(4):763-770.

2. Eckstein H.-H, Niedermeier H.-P, T. Noppeney, T. Umscheid, H. Wenk, H. Imig. Certification of Vascular Centers - A Project of the German Society for Vascular Surgery.J Vasc Surg. sept.2006:32(3): 279-285.

3. Becker G.J,Katzen B.T.The vascular center:A model for multidisciplinary delivery of vascular care for the future.J Vasc Surg. may.1996:23(5):907-912

4. www.advisory.com, Vascular Centers of Excellence: A Tactical Approach
5. www. link.springer.com.Roizen M.F. Anesthesiology and the HeartAnesthesia for Vascular Surgery.1990:305-346

6. www.lf.upjs.sk/ceea/doc2/9_Klima_periferne_cievy.pdf. Klima R. Anesthesia for Vascular Surgery.

7. Rutherford R.B.Qualifications of the physician in charge of the vascular diagnostic laboratory.J Vasc Surg.dec.1988

8. Radak Dj.Karotidna Hirurgija,Beograd 2012;97-98,129

9. Nguyen L.,Barshes N. Analysis of large databases in vascular surgery. J Vasc Surg.sept. 2010.UPUTSTVO NAŠIM SARADNICIMA 